\title{
In vivo protective effect of the lectin from Canavalia brasiliensis on BALB/c mice infected by Leishmania amazonensis
}

\author{
M. Barral-Netto ${ }^{a, b}, *$, R.L. Von Sohsten ${ }^{a}$, M. Teixeira ${ }^{a}$, W.L. Conrado

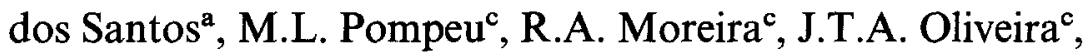 \\ B.S. Cavada ${ }^{\text {c }}$, E. Falcoff ${ }^{d}$, A. Barral ${ }^{\text {a }}$ \\ ${ }^{a}$ Serviço de Imunologia, Hosp. Univ. Prof. Edgard Santos, Universidade Federal da Bahia, Bahia, Brazil, \\ ${ }^{b}$ LIMI, Centro de Pesquisas Gonçalo Moniz, FIOCRUZ, Salvador, Bahia, Brazil ' Departamentos de \\ Patologia \& Bioquimica, Universidade Federal do Ceará, Ceara, Brazil Institut Curie, Unité INSERM 196,
} Paris, France

Received 9 August 1995

In vivo administration of Canavalia brasiliensis lectin (at the time of infection, or maintained throughout the infection) reduced the lesions of highly susceptible BALB/c mice infected by Leishmania amazonensis. At the doses used C. brasiliensis lectin (ConBr) does not interfere with penetration or fate of Leishmania in the macrophages in vitro. Since Interferon- $\gamma$ (IFN- $\gamma$ ) is the major macrophage activating factor, and considered a critical element in the successful immune response against leishmaniasis, we explored its participation in this phenomenon. ConBr either in vivo or in vitro induced IFN- $\gamma$ production in normal or in leishmania-infected BALB/c mice. However we were unable to change the course of disease by in vivo IFN- $\gamma$ administration (although IFN- $\gamma$ preparations were effective in inducing a leishmanicidal effect in vitro on $L$, amazonensis-infected peritoneal macrophages). Additionally, IFN- $\gamma$ neutralization with antiIFN- $\gamma$ monoclonal antibody did not alter the protection conferred by $\mathrm{ConBr}$ administration. These data show that lectin administration in vivo is protective in the otherwise unchecked $L$. amazonensis infection of BALB/c mice, and suggest that such effect is not mediated by IFN- $\gamma$.

Key words: Leishmania amazonensis; Leishmaniasis; Leishmania; Tegumentary leishmaniasis; Experimental leishmaniasis; Canavalia brasiliensis; Interferon- $\gamma$

Host resistance against leishmania infection depends on cell-mediated immunity (CMI) (Scott et al., 1988; Kiderlen et al., 1984; Louis et al., 1979; Howard et al., 1981; Titus et al., 1985). IFN- $\gamma$ is considered an important element in this response by three lines of evidence: mouse strains susceptible to leishmania infection have a low production of IFN- $\gamma$ whereas resistant strains produce high amounts of this lymphokine (Murray et al., 1982; Sadick et al., 1986); IFN- $\gamma$ in vitro stimulates macrophages to kill leishmania (Titus et al., 1984; Murray et al., 1983), and resistant mouse strains such as $\mathrm{C} 3 \mathrm{H} / \mathrm{HeN}$ or $\mathrm{BALB} / \mathrm{c}$ can be rendered susceptible to $L$. major

Correspondence address: Dr. Manoel Barral-Netto, Serviço de Imunologia-HUPES-UFBA. R. João das Botas, s/n. 40.140 Salvador, Bahia, Brazil. Phone (55-71) 237-7353; FAX (55-71) 245-7110; e-mail: barral@ufba.br 
or $L$. donovani, respectively, by the use of anti-IFN- $\gamma$ MAb (Belosevic et al., 1989; Squires et al., 1989).

Several lectins are known as lymphocyte activators, inducing proliferation and lymphokine production. Some lectins, such as Con A from $C$. ensiformis, are standard reagents for in vitro lymphocyte studies. ConBr, from $C$. brasiliensis, stimulates lymphocytes inducing higher lymphocyte proliferative responses and IFN- $\gamma$ production than several other lectins, including Con A (Barral-Netto et al., 1992b). The use of some natural products in vivo results in lymphocyte stimulation, and may mediate important functions as prevention of malignant tumor outgrowth (Newell et al., 1991). Recently orally administered lectins have been shown to stimulate human immune response (Luther et al., 1990). Con A is also capable of inducing lymphocyte proliferation and IL-2 production when administered in vivo (Black et al., 1988).

The mouse models of leishmaniasis reproduce different aspects of the human disease. Upon infection by $L$. amazonensis the highly susceptible BALB/c mice develop a severe disseminated disease, with fatal course, and this severity is paralleled by a lack of CMI responses against leishmania antigen. On the other hand, C57BL/6 mice when infected by the same parasite develop a single ulcerated lesion, which evolves to an apparent cure. Months after the initial infection, and coincident to the decline of CMI in the aging animals, the infected mice develop a metastatic disease, resembling mucocutaneous leishmaniasis (Barral et al., 1983).

Based on the potent lymphocyte stimulatory capacity of $\mathrm{ConBr}$ we decided to evaluate its in vivo effect on the course of $L$. amazonensis infection in BALB/c mice, and a possible participation of IFN $-\gamma$ in the process.

\section{Material and methods}

Animals. BALB/c mice were obtained from our own colony, maintained with commercial balanced mouse ration and water ad libitum. OF/1 mice were obtained from Institute Pasteur (Paris-France).

Parasites. L. amazonensis (MHOM/BR/76/Josefa) was used. Details of isolation, maintenance and course of disease in mice have been reported elsewhere (BarralNetto et al., 1987b).

Infection. Stationary-phase promastigotes $\left(5 \times 10^{6} /\right.$ animal $)$ from modified liver infusion tryptose medium (Barral et al., 1987) were injected s.c. into the left hind footpad. Evolution of infection was monitored by weekly measurement of foot-pad thickness with a dial gauge caliper (Starret Co., Athol, MA). Differences between infected and contralateral uninfected footpad are referred as lesion size, in millimeters.

Lectin and treatment. ConBr was obtained according to the methods previously described (Moreira and Cavada, 1984), and used at $100 \mu \mathrm{g}$ per animal per dose, injected i.p.. Groups of 10 animals were either treated three times, at days $-1,0$ and 1 of infection, or with weekly doses of the lectin during the whole period of observation. Untreated controls were injected i.p. at the same schedules with saline. 
Interferon $\gamma$ : Two preparations of IFN- $\gamma$ were used. Recombinant murine IFN- $\gamma$ $\left(5 \times 10^{6} \mathrm{IU} / \mathrm{mg}\right.$ of protein; Genentech Corp., South San Francisco, CA), and recombinant rat IFN $-\gamma\left(2.5 \times 10^{6} \mathrm{IU} / \mathrm{mg}\right.$; Institut Roussel Uclaf, Romainville, France). Rat IFN- $\gamma$, used in vivo in mice, stimulates the respiratory burst of peritoneal macrophages at an optimal dose of $5000 \mathrm{IU} /$ animal (Dr. Michel Lando, personal communication). Both preparations were administered subcutaneously.

Anti-IFN- $\gamma$ MAb: Mice were treated i.p. with $500 \mu \mathrm{g}$ of neutralizing anti-IFN- $\gamma$ antibody XMG 1.2 (rat IgG1) at time of infection, and with $300 \mu \mathrm{g}$ three times a week during the whole period of observation.

Macrophage culture and in vitro infection: $B A L B / c$ resident peritoneal macrophages were washed 3 times in RPMI 1640, and resuspended, in RPMI 1640 with $10 \%$ heat inactivated FCS (fetal calf serum, GIBCO; Grand Island, NY). Five $\times 10^{5}$ to $2 \times 10^{6}$ cells/well were plated in 8 chamber Lab-Tek slides (Miles Laboratories, Naperville, IL) and incubated for $2 \mathrm{~h}$ at $37^{\circ} \mathrm{C}$ in a humid atmosphere of $5 \% \mathrm{CO}_{2}$. Non-adherent cells were removed by repeated washings. The cultures were incubated with leishmania promastigotes at a ratio of $10: 1$ for $3 \mathrm{~h}$ at $35^{\circ} \mathrm{C}$ in $5 \% \mathrm{CO}_{2}$ and $95 \%$ humidified air. Free parasites were then removed by extensive washings. Different IFN- $\gamma$ concentrations were added to duplicate wells in RPMI 1640 with $10 \%$ FCS. In some cultures $\mathrm{ConBr}$ was added, at different concentrations, before parasite exposure and maintained throughout the culture period. The slides were incubated for another $24 \mathrm{~h}$ followed by washings with PBS. The cells were fixed and stained with Diff Quick (American Scientific Laboratories, McGaw Park, IL). Infection was estimated by calculating the percentage of infected macrophages, as well as the number of parasites per 100 cells in duplicate cultures.

In vivo kinetics of radiolabelled IFN- $\gamma$ : $\mathrm{rMu}$ IFN- $\gamma$ was labelled with $125_{\text {I }}$ by the chloramine T method. Labelled IFN- $\gamma$ had $1,6 \times 10^{7} \mathrm{CPM} / \mathrm{ml}$ and maintained its biological activity $\left(1 \times 10^{4} \mathrm{IU} / \mathrm{ml}\right.$, as measured by a vesicular stomatitis virus (vsv) plaque reduction assay. Thirty female 6 to 7 week-old OF-1 mice were injected in the left hind footpad with $25 \mu$ l of radiolabelled IFN- $\gamma$ solution and groups of 5 mice were sacrificed at 6 time points (time zero corresponding to sacrifice immediately after injection). Blood samples were heparinized and duplicate samples of $50 \mu \mathrm{l}$ blotted on Whatman filter paper. Radioactivity was measured in one untreated sample, the other sample was incubated with $10 \%$ TCA for $15 \mathrm{~min}$ at $4^{\circ} \mathrm{C}$. The $10 \%$ TCA solution was changed once, followed by two incubations with $5 \%$ TCA, and finally replaced by an alcohol ether $(50 / 50 \mathrm{v} / \mathrm{v})$ solution. Filter papers were collected, dried and counted. Both hind feet were obtained from each animal by sectioning above the joint and counted directly.

Stimulation of IFN- $\gamma$ production. For evaluation of in vivo IFN- $\gamma$ production 5 BALB/c mice were treated i.p. with $\mathrm{ConBr}(100 \mu \mathrm{g} / \mathrm{animal})$ and had their blood collected $24 \mathrm{~h}$ later. IFN- $\gamma$ was measured in serum, and compared to uninjected animals. For in vitro stimulation spleen cells were obtained from 3 normal BALB/c mice and cultured in RPMI 1640 (GIBCO, Grand Island, NY), supplemented with glutamine $(100 \mathrm{mM}), 2-\mathrm{ME}\left(5 \times 10^{-5} \mathrm{M}\right)$, penicillin $(100 \mathrm{U} / \mathrm{ml})$ and streptomycin $(100 \mu \mathrm{g} / \mathrm{ml})$, at a concentration of $5 \times 10^{6}$ cells $/ \mathrm{ml}$. Supernatants from either stim- 
ulated (ConBr $5 \mu \mathrm{g} / \mathrm{ml}$ ) or unstimulated cultures (in duplicate) were harvested at $24 \mathrm{~h}$ for IFN- $\gamma$ measurements.

IFN- $\gamma$ determination. IFN- $\gamma$, either in serum or culture supernatant, was measured by a virus plaque reduction assay using L929 cells and Vesicular Stomatitis Virus. That the reduction was due to IFN- $\gamma$ was demonstrated by inhibiting the anti-viral effect of the preparations by pre-treatment with XMG 1.2 MAb.

Histology. BALB/c mice from groups treated with lectin or controls ( $\mathrm{n}=5$ per group) were sacrificed at 5 and 8 weeks post-infection and infected foot-pads obtained. The material was fixed in formalin, embedded in paraffin and processed for hematoxylin and eosin staining.

Statistics. Group means were compared by the Mann-Whitney test, and differences were considered significant if $\mathrm{p}<0.05$.

\section{Results}

Effect of in vivo lectin administration on lesion growth. Administration of ConBr to $\mathrm{BALB} / \mathrm{c}$ mice during the time of their infection with $L$. amazonensis ( 1 day before, at the day of infection, and 1 day after) conferred a partial degree of protection to these animals, as compared to saline treated controls (Fig. 1). Differences in lesion size between the two groups were statistically significant after the fifth week of infection. The prolonged use of $\mathrm{ConBr}$, during the 8 weeks of observation, at a dose

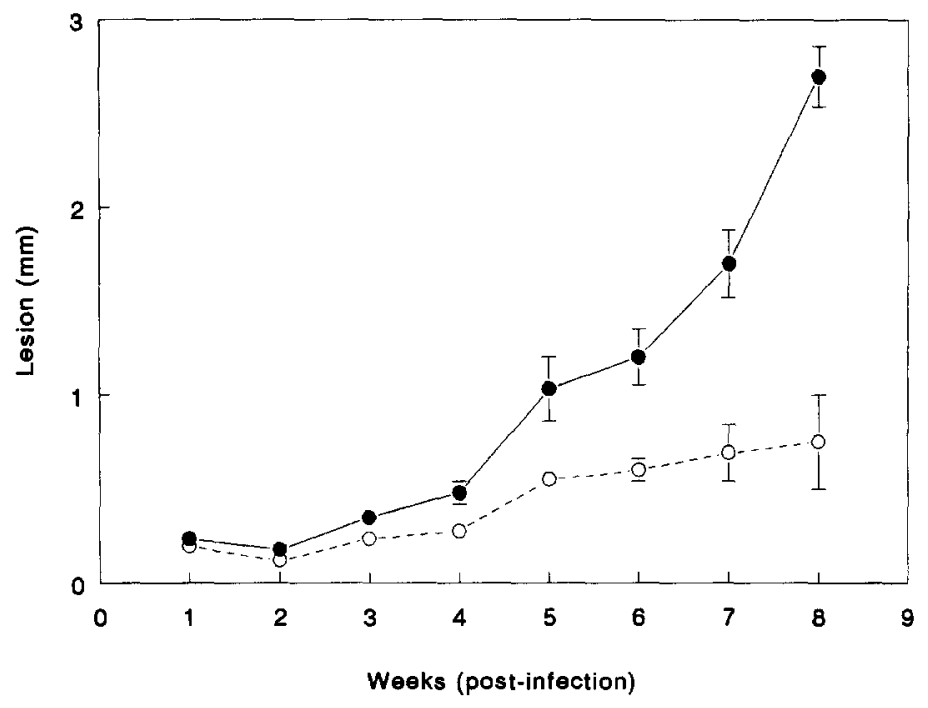

Figure 1. Effect of ConBr on the course of infection of BALB/c mice. Groups of $10 \mathrm{BALB} / \mathrm{c}$ mice were infected with $5 \times 10^{6} \mathrm{~L}$. amazonensis promastigotes in the left hind footpad and treated with $\mathrm{ConBr}$ at days $-1,0$ and 1 of infection $(100 \mu \mathrm{g} /$ animal i.p.; open circles) or saline (closed circles). Lesion size (in $\mathrm{mm}$; mean $\pm \mathrm{SD}$ ) represents the difference between the infected footpad and the contralateral uninfected one. 
of $100 \mu \mathrm{g} /$ animal/week, starting at the day of infection, resulted in a degree of protection similar to the one obtained with the use of the lectin at the time of infection only (data not shown).

Histopathology. At 5 weeks post-infection BALB/c ConBr-treated mice exhibited less parasites than saline-treated controls. Saline treated animals exhibited an intense inflammatory infiltrate represented by large vacuolated and heavily parasitized macrophages (Fig. 2 A,C). Extensive areas of purulent necrosis and collections of neutrophils were also observed. The inflammatory infiltrate of ConBr-treated animals was composed of non-vacuolated macrophages and lymphocytes (Fig. 2 B,D). There was proliferation of fibroblastic cells in the periphery of the lesion, and a discrete production of conjunctive tissue.

At 8 weeks post-infection the histopathological differences between the two groups were even more marked. The inflammatory infiltrate of ConBr-treated animals exhibited a profound decrease in the number of parasitized macrophages, and a correspondent increase in the number of lymphocytes. The presence of fibrinoid necrosis was frequently observed; with fibrogenesis of moderate intensity and formation of thin septa towards the interior of the lesion. On the other hand, salinetreated animals exhibited an inflammatory infiltrate represented by vacuolated macrophages with an adipocyte-like appearance (approximately $60 \%$ of cells in the lesions) harboring a large number of parasites.

IFN- $\gamma$ production. Table I shows that $\mathrm{ConBr}$ was able to induce IFN- $\gamma$ production by naive or leishmania-infected BALB/c spleen cells upon in vitro stimulation, and was also able to induce the appearance of IFN- $\gamma$ in the sera of animals injected i.p..

Effects of in vivo IFN- $\gamma$ administration. Administration (subcutaneously, not at the site of the infection) of recombinant IFN- $\gamma$ at the beginning of infection, three doses of either $5 \times 10^{3}$ (data not shown) or $2 \times 10^{4} \mathrm{IU} / \mathrm{mouse} /$ day at days $-1,0$, and 1 of infection (Fig. 3, Panel A), or weekly for the whole period of observation (Fig. 3, Panel B) did not alter the course of $L$. amazonensis infection in BALB/c mice.

Kinetics of radiolabelled IFN- $\gamma$ : Serum kinetics of $125_{\mathrm{I}}$ IFN- $\gamma$ ( 250 IU corresponding to $412.000 \mathrm{CPM}$ /animal) is shown in Figure 4. The material diffuses rapidly away from the injection site and $15 \mathrm{~min}$ after injection less than half the counts obtained at time zero were recovered from the injected foot pad, and radiolabelled IFN- $\gamma$ could be detected in the contralateral foot pad (2,315 and 1,962 CMP one and $2 \mathrm{~h}$ after injection). Radioactivity is also detected as a TCA-precipitable material in serum, showing that it is bound to a large molecule (insert of Fig. 4). Considering that the ${ }^{125} \mathrm{I}$-labelled IFN- $\gamma$ contained $1 \times 10^{4} \mathrm{IU} / \mathrm{ml}$ with $1.6 \times 10^{7} \mathrm{CPM} / \mathrm{ml}$, approximately 1 IU out of the 250 IU of IFN- $\gamma$ injected reached the contralateral foot pad, in a few hours. Also according to these data, amounts greater than $10 \mathrm{U}$ of IFN- $\gamma$ remained in the injected footpad for more than $7 \mathrm{~h}$.

Use of IFN- $\gamma$ in vitro: In 3 experiments both rRat and rMu IFN- $\gamma$ were capable of inducing amastigote killing by mouse peritoneal macrophages. The effect was most marked at $1,000 \mathrm{IU} / \mathrm{ml}$, but reduction of parasitism was statistically significant even at $10 \mathrm{IU} / \mathrm{ml}$ (Table II). Another experiment showed that $\mathrm{rMu} \mathrm{IFN}-\gamma$ was more 

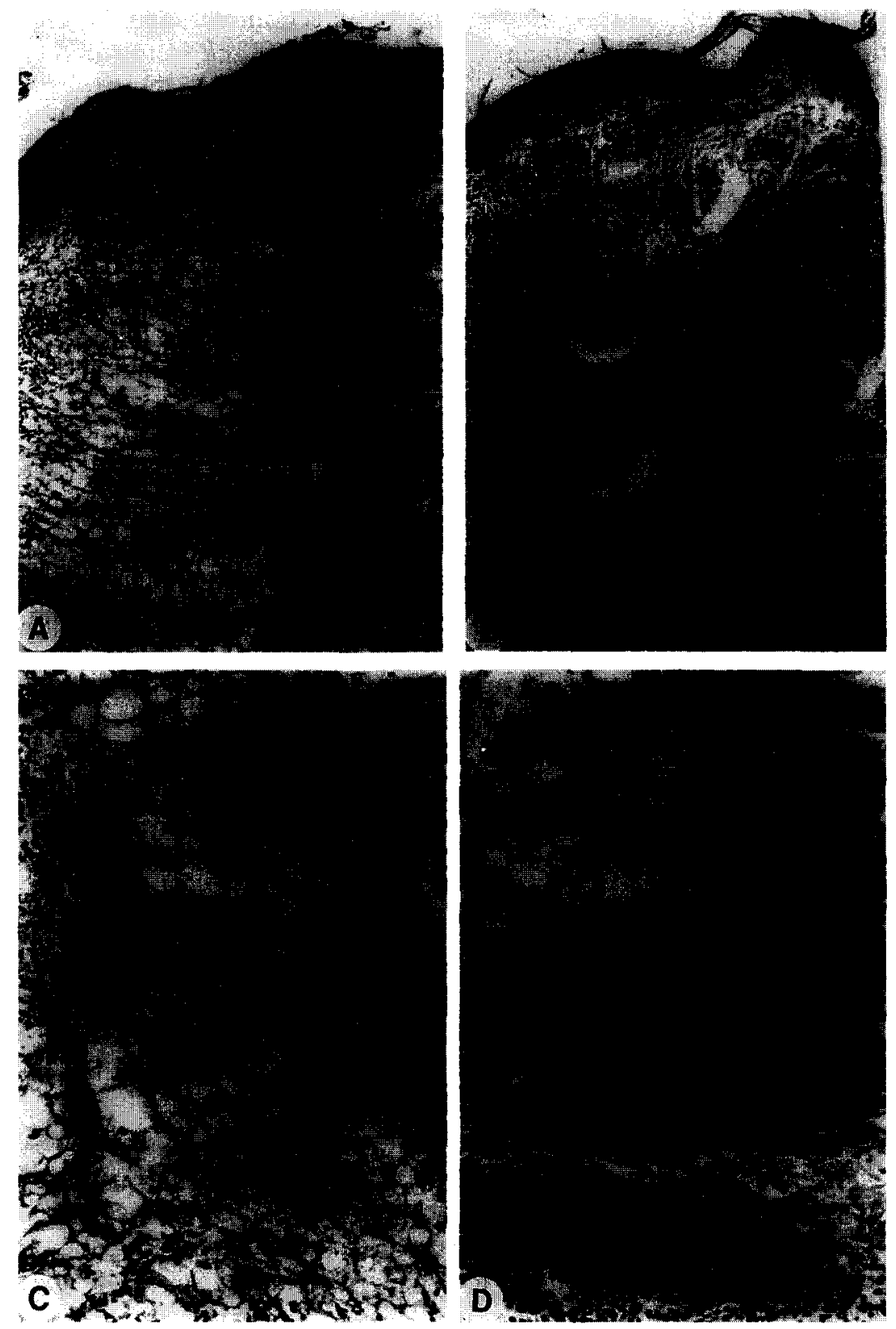

Figure 2.A. Lesion of untreated BALB/c mouse 4 weeks after infection with $L$. amazonensis. A large collection of vacuolated macrophages (arrowheads indicate the area) occupies most of the section). $100 \times$.

B. Lesion of ConBr treated (days $-1,0$ and +1 of infection) BALB/c mouse 4 weeks after L. amazonensis infection. Arrowheads point to concentrations of lymphocytes, and vacuolated macrophages are rare. $100 \times$.

C. A larger magnification of $2 \mathrm{~A}$. It is possible to observe the presence of several leishmania promastigotes in the interior of macrophages (arrowheads point to some of them). $200 \times$.

D. A larger magnification of $2 \mathrm{~B}$. Several lymphocytes are observed, and almost no macrophages harboring parasites. $200 \times$. 
TABLE 1

In vivo and in vitro induction of IFN- $\gamma$ by $\mathrm{ConBr}$ in uninfected or $L$. amazonensis-infected BALB/C mice

\begin{tabular}{|c|c|c|}
\hline \multirow[b]{2}{*}{ Stimulus } & \multicolumn{2}{|l|}{ IFN- $\gamma(\mathrm{IU} / \mathrm{ml})$} \\
\hline & Serum $\triangle$ & Culture SN* \\
\hline Uninfected-ConBr & $104.7 \pm 35.2^{* *}$ & $375.0 \pm 176.8$ \\
\hline Infected-ConBr ${ }^{+}$ & $166.4 \pm 85.9$ & $281.6 \pm 210.3$ \\
\hline None $^{++}$ & $<4$ & $<4$ \\
\hline
\end{tabular}

$\triangle$ Serum was collected $24 \mathrm{~h}$ after ip injection of $100 \mu \mathrm{g}$ of ConBr.

* Supernatant from $24 \mathrm{~h}$ cultures of BALB/c spleen lymphocytes stimulated in vitro with $\mathrm{ConBr}(5 \mu \mathrm{g} / \mathrm{ml})$.

** Mean \pm S.D. (of 5 determinations).

${ }^{+}$One week after $L$. amazonensis infection.

${ }^{++}$Unstimulated cultures from both uninfected and infected animals did not have measurable IFN- $\%$.

active than rRat IFN- $\gamma$ in inducing anti-leishmanial activity in murine macrophages (\% reduction of parasitism of 58 vs 30 , respectively, at a dose of $10 \mathrm{IU} / \mathrm{ml}$ ).

Effect of ConBr on in vitro macrophage cultures. The presence of $\mathrm{ConBr}(1,10$ or $100 \mu \mathrm{g} / \mathrm{ml}$ ) in macrophage cultures did not alter the rate of infection both as measured by the number of parasites per 100 macrophages, or by the percentage of infected cells, as compared to untreated cultures (Fig. 5). The presence of ConBr $(10 \mu \mathrm{g} / \mathrm{ml})$ in macrophage cultures infected with $L$. amazonensis also did not affect the anti-leishmanial activity of $\mathrm{rMu}$ IFN- $\gamma(10 \mathrm{IU} / \mathrm{ml})$. In rMu IFN- $\gamma$-treated cultures the presence of ConBr resulted in reduction of parasitism of 65 and $63 \%$, whereas cultures without $\mathrm{ConBr}$ reduction was of 68 and $64 \%$.

Effect of anti-IFN- $\boldsymbol{y}$ MAb. Groups of four BALB/c mice were treated with ConBr ( $100 \mu \mathrm{g} /$ animal i.p. at days $-1,0$ and 1 of infection) or with the same schedule of ConBr plus anti-IFN- $\gamma(500 \mu \mathrm{g} /$ animal initially and $300 \mu \mathrm{g} / \mathrm{animal} / \mathrm{dose}$, i.p., of XMG 1.2 antibody, 3 times/week for 8 weeks); or treated with saline alone at the same intervals. The treatment with anti-IFN- $\gamma$ MAb did not alter the protective effect induced by ConBr (Fig. 6).

\section{Discussion}

Our results show that in vivo administration of $\mathrm{ConBr}$ is able to protect, but not cure, the highly susceptible BALB/c mice against $L$. amazonensis infection. Such treatment also stimulated lymphocytes, as evidenced by IFN- $\gamma$ production, and by the development of a histological pattern observed only in resistant mice, such as lymphocytic infiltration and fibrinoid necrosis (Andrade et al., 1984; Barral-Netto et al., 1987a). In our model, however, IFN- $\gamma$ production and protection do not seem to be interlinked, since the use of anti- IFN- $\gamma$ MAb did not reduce the lectin-induced protection.

Other actions of the lectin, besides the production of IFN- $\gamma$, are probably responsible for such an effect. Con $\mathrm{A}$, a lectin very similar to ConBr, has been shown to induce the increase in the number and size of lymphocytes, with the expression of 

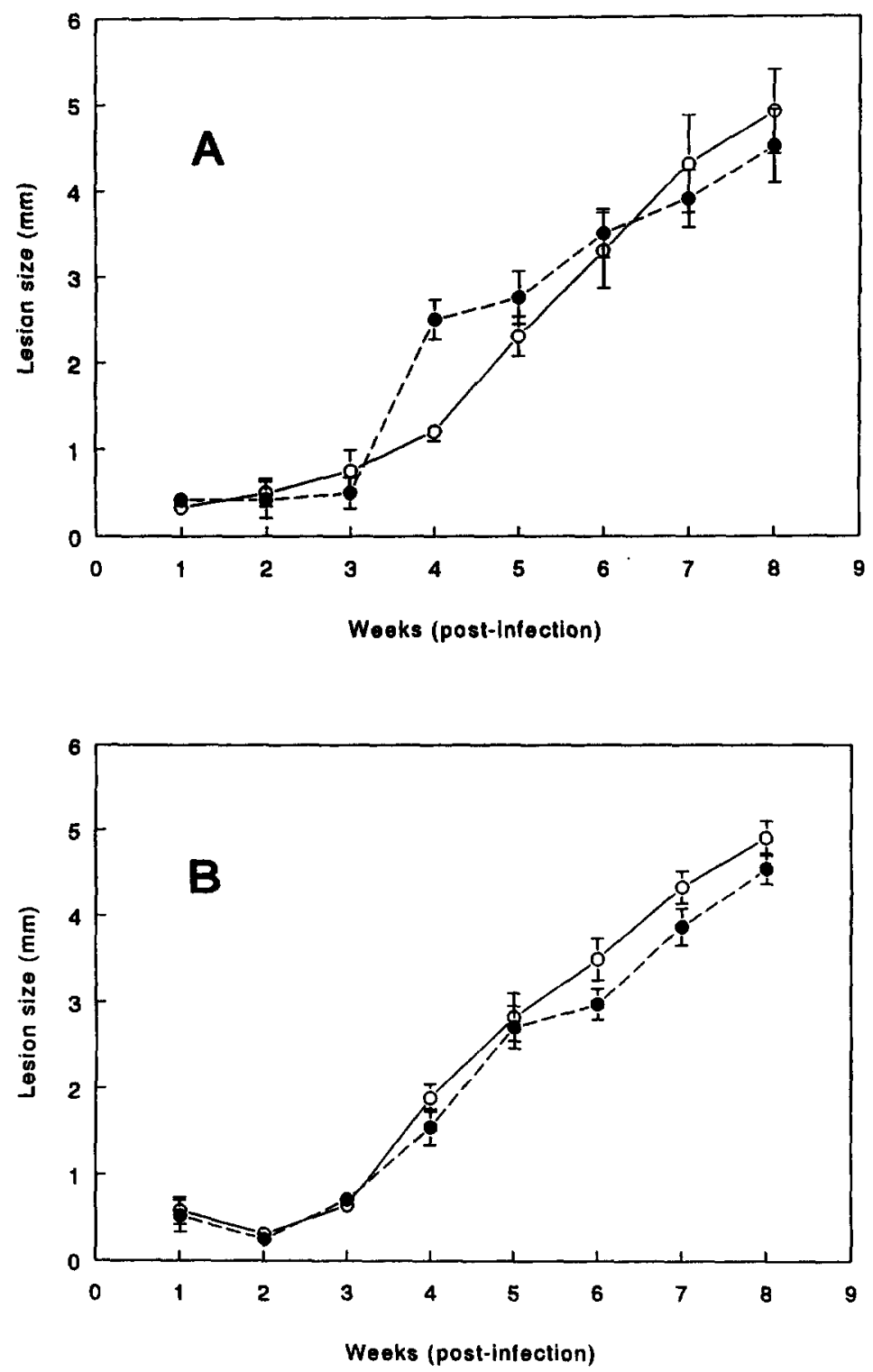

Figure 3. Lack of effect of high dose of IFN- $\gamma$ in changing the course of $L$. amazonensis infection in BALB/c mice. Groups of 10 mice (infected and evaluated as in Figure 1) were treated with $2 \times 10^{4} \mathrm{IU}$ of rRat IFN- $\gamma$ (open circles) or saline (closed circles), either at days $-1,0$ and 1 of infection (A) or 3 times a week countinuously during the observation period (B).

IL-2R and spontaneous proliferation when administered in vivo (Black et al., 1988). It is possible that many other, not explored, lymphocyte functions are involved in the protective effect. Whichever this effect was, it is remarkable that the use of the lectin just at time of infection was capable of achieving protection. The in vivo administration of Con $\mathrm{A}$ has a transient effect on the immune system, with return to normal parameters in approximately $24 \mathrm{~h}$ (Black et al., 1988). The immune 


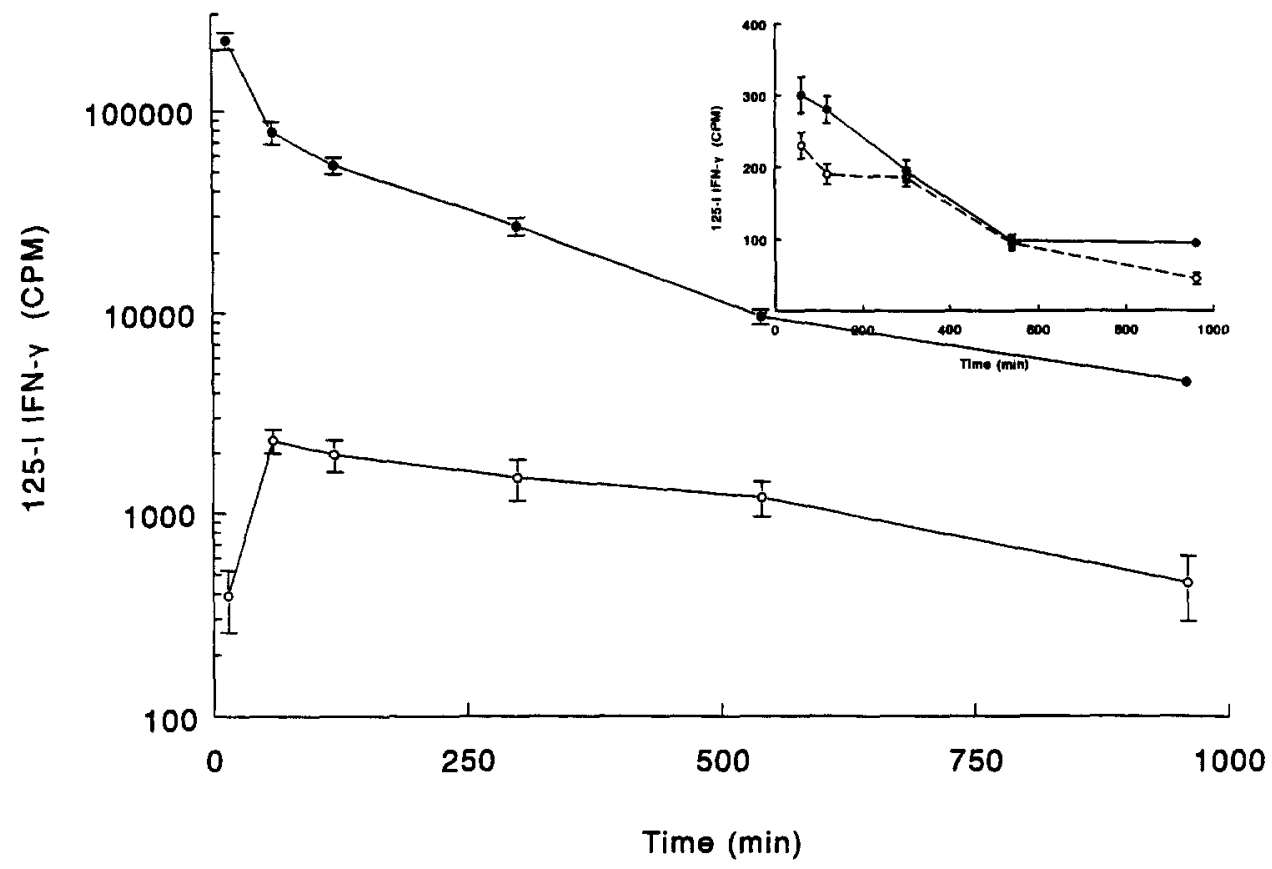

Figure 4. Kinetics of radiolabelled IFN- $\gamma$ in vivo. OF-1 mice were injected s.c. with $250 \mathrm{IU}$ of ${ }^{125} \mathrm{I}-\mathrm{rMu}$ IFN- $\gamma$ (with an activity of $1.6 \times 10^{3} \mathrm{cpm} / \mathrm{IU}$ ), in the left hind footpad and sacrificed at different time points and radioactivity was measured directly in the injected footpad (closed circles) and in the uninjected one (open circles). Measurement in serum is shown in the insert, as total counts (closed circles), or as a TCA-precipitable molecule (open circles). Each time point is shown as mean \pm SD of 6 determinations.

\section{TABLE II}

Effect of recombinant rat interferon $\gamma$ on leishmanicidal capacity of BALB/c resident peritoneal macrophages infected in vitro by $L$. amazonensis

\begin{tabular}{|c|c|c|c|}
\hline $\begin{array}{l}\text { IFN- } \gamma \text { dose } \\
(\mathrm{IU} / \mathrm{ml})\end{array}$ & 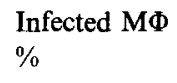 & $\begin{array}{l}\text { Amastigotes } \\
\text { per } 100 \text { cells }\end{array}$ & $\begin{array}{l}\% \text { reduction } \\
\text { of parasitism }\end{array}$ \\
\hline 0 & $87.3 \pm 5.0$ & $462.7 \pm 181.4$ & \\
\hline 10 & $67.7 \pm 5.1$ & $249.3 \pm 96.8$ & $46.12 \pm 9.3$ \\
\hline 100 & $45.0 \pm 4.4$ & $132.0 \pm 96.3$ & $71.47 \pm 3.4$ \\
\hline 1000 & $33.7 \pm 2.5$ & $69.0 \pm 15.6$ & $85.09 \pm 0.7$ \\
\hline
\end{tabular}

Results expressed as mean + S.D. of 3 experiments.

activation during the critical period of infection is capable of altering the course of disease, without further improvement with the maintenance of activation for a longer period.

The participation of glycoproteins in the process of penetration of leishmania into the macrophage has been shown (Bray, 1983), what raises the possibility of a direct effect of the lectin, hindering the parasite entry into the host cell, and leading to its extracellular destruction. Although we cannot exclude this possibility, it seems unlikely. In our system the presence of the lectin did not change the penetration or fate of leishmania inside the macrophage in the in vitro cultures. Promastigote 


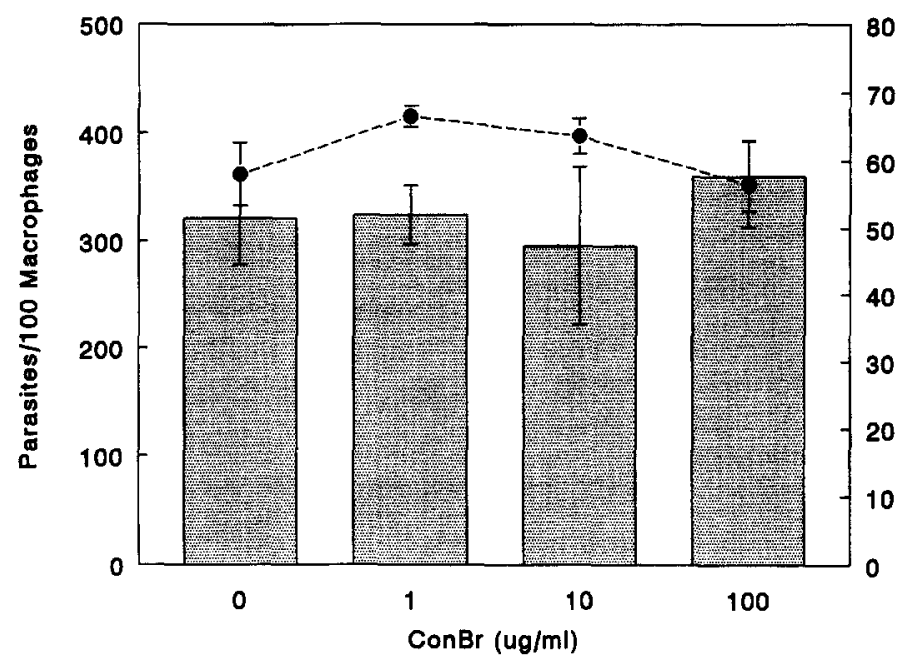

Figure 5. Lack of effect of $\mathrm{ConBr}$ on parasite survival in macrophage cultures. BALB/c resident peritoneal macrophages $\left(5 \times 10^{5}\right.$ cells/well $)$ were treated with different concentrations of $\mathrm{ConBr}$ for the whole period of culture. Cultures were infected with $L$. amazonensis stationary-phase promastigotes (10:1 parasite : cell ratio) for $3 \mathrm{~h}$. Free parasites were removed and cultures continued for $24 \mathrm{~h}$. Bars represent number of parasites per 100 cells (left $\mathrm{Y}$-axis), and circles the percentage of infected macrophages (right $\mathrm{Y}$-axis); mean \pm S.E.M. of six cultures.

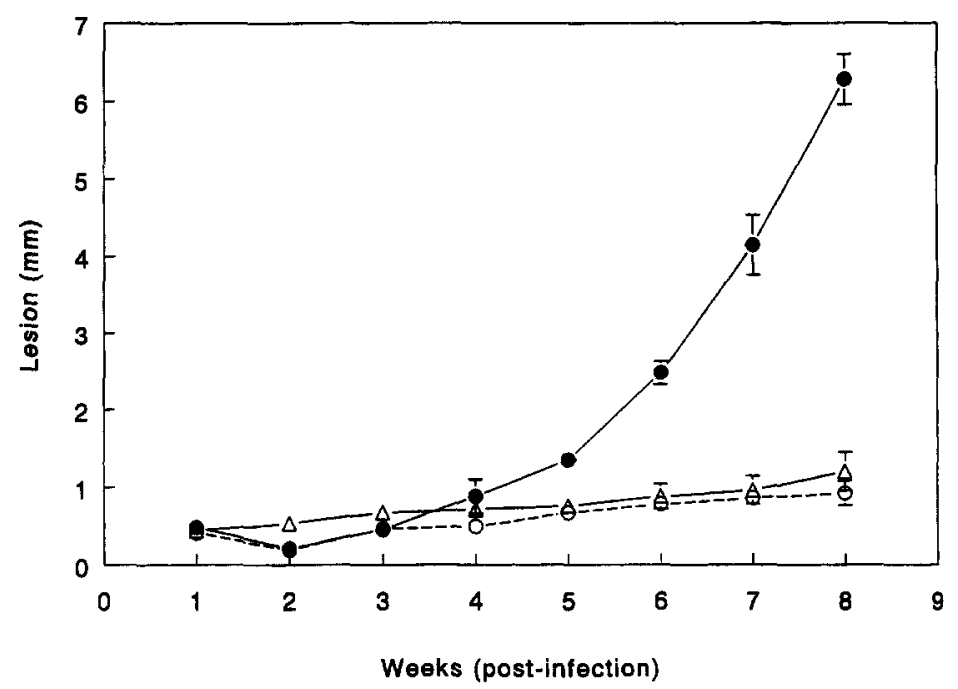

Figure 6. Effect of anti- IFN- $\gamma$ MAb on the protective action of ConBr. Groups of 6 BALB/c mice (infected and evaluated as in Figure 1) were treated with $\operatorname{ConBr}(100 \mu \mathrm{g} /$ animal i.p. at days $-1,0$ and 1 of infection; open circles), with ConBr (as above) plus XMG 1.2 anti- IFN- $\gamma$ mAb ( $500 \mu \mathrm{g} /$ animal initially, and $300 \mu \mathrm{g} /$ animal i.p., 3 times/week for eight weeks; open triangles) or saline (closed circles).

agglutination in vitro has been observed with several species of leishmania, but these studies were performed in sugar-free PBS, and even then agglutinating concentrations ranged from $50 \mu \mathrm{g} / \mathrm{ml}$ to $10 \mathrm{mg} / \mathrm{ml}$ (Dwyer, 1974; Jacobson et al., 1982), concentrations far above those that could be achieved by the administration of $100 \mu \mathrm{g}$ of lectin per animal. 
The possibility of an immune response directed against the lectin itself reacting against possible cross-reacting parasite epitopes it is unlikely, but cannot be excluded. The presence of the lectin just for 3 days during the period of infection, given i.p. without adjuvant, is not likely to induce a potent immune response, and even if it does such a response would not be operative in such a short time.

We were not able to change the natural course of $L$. amazonensis infection in susceptible BALB/c mice by exogenously administered IFN- $\gamma$, as has been shown for the infection with $L$. major (Sadick et al., 1990). Despite these results we should consider the possibility that only IFN- $\gamma$ produced very early in infection is elemental for protection, and that $\mathrm{ConBr}$ administered before infection induced such a production. We have used IFN- $\gamma$ starting one day before infection allowing for this possibility and observed no protection. Conversely, the use of anti-IFN- $\gamma$ at time of infection did not change the protective effect obtained by the ConBr treatment.

Both IFN- $\gamma$ preparations used in this study were biologically active, as demonstrated by in vitro assays of intracellular killing of $L$. amazonensis in murine peritoneal macrophages. Based on our in vivo kinetics experiments ( 1 out of $250 \mathrm{IU}$ reaching a site distant of injection) amounts greater of approximately $20 \mathrm{IU}$ (for doses of 5,000 IU; data not shown) or $80 \mathrm{IU}$ (for doses of $2 \times 10^{4} \mathrm{IU}$ ) of IFN- $\gamma$ were expected to have been reached in the lesion, which are similar to doses effective in vitro. The lack of in vivo activity of IFN- $\gamma$ despite the evidence of in vitro effectiveness, as shown in the present study, was also observed in other systems (Van Dissel et al., 1987). We cannot determine whether the contrasting findings between in vitro-treated peritoneal macrophages and in vivo-treated cutaneous macrophages at lesion sites are due to lack of proper stimulation or to a defective leishmanicidal capacity of cutaneous macrophages. Macrophages from footpad granulomas of Mycobacterium leprae-infected susceptible nu/nu mice could not be activated in vitro by IFN- $\gamma /$ MAF to kill or inhibit Toxoplasma gondii whereas peritoneal macrophage from the same mice were successfully activated (Sibley and Krahenbuhl, 1987).

The evidence for an in vivo role of IFN- $\gamma$ in murine models of cutaneous leishmaniasis is not as strong as shown in vitro. Resistant animals even when treated with anti- IFN- $\gamma$ MAb were able to control lesion growth (Belosevic et al., 1989; Sadick et al., 1990). Lymphoid cells from CBA mice naturally resistant or rendered susceptible by anti-CD4 MAb treatment exhibited mRNA coding for IFN- $\gamma$ after $L$. majorinfection. Furthermore, only in the lesions of anti-CD4 treated mice showing uncontrolled growth was IFN- $\gamma$ mRNA found (Muller et al., 1989). Additionally, the use of generous amounts of IFN- $\gamma$, or the transfer of a cell which produces IFN- $\gamma$ did not protect susceptible animals against cutaneous leishmaniasis (Sadick et al., 1990; Titus et al., 1991). It has been shown that the use of anti-IFN- $\gamma$ MAb do not alter the protection of BALB/c treated with anti-IL 4 (Sadick et al., 1990), and also that immunized and protected BALB/c mice produce high levels of TNF $\alpha$ but not of IFN- $\gamma$ (Boom et al., 1990; Theodos et al., 1991). IFN- $\gamma$ does not seem to participate in the early regulation of visceral leishmaniasis in the mouse (Kaye and Bancroft, 1992). Additionally, IL-4 production but not IFN- $\gamma$ production correlated with severity of leishmaniasis when evaluated in thirteen inbred mouse strains covering the range of susceptibility to disease caused by $L$. major (Morris et al., 1993).

The anti-leishmanial effect of IFN- $\gamma$ used alone, against visceral leishmaniasis, was augmented when combined with pentavalent antimonial (Murray, 1990). It is possible that the beneficial effects of IFN- $\gamma$ in leishmaniasis are due to a combined 
action with anti-leishmanial agents and not only through a direct leishmanicidal action (Badaro et al., 1990; Murray et al., 1988). It is also possible that IFN- $\gamma$ is more effective when used alone in visceral leishmaniasis, either because $L$. donovani is more susceptible, or because liver and spleen macrophages (due to influences of neighbor cells or temperature, for example) are more responsive to the activating effects of IFN- $\gamma$.

It should also be considered the possibility that other elements, which may synergize with IFN- $\gamma$, like TNF- $\alpha$ (Titus et al., 1989; Liew et al., 1990), and GM-CSF (Ho et al., 1990; Weiser et al., 1987; Handman and Burgess, 1979), may also be lacking, and IFN- $\gamma$ alone is not suficient to induce protection in susceptible animals. Another possibility is the inhibition of the actions of IFN- $\gamma$ in animals susceptible to cutaneous leishmaniasis by a large production of cytokines like IL-10 or TGF- $\beta$ (Heinzel et al., 1991; Barral-Netto et al., 1992a; Barral et al., 1993), explaining the failure of exogenously administered IFN $-\gamma$.

Although the intra-peritoneal use of a lectin may not be feasible for enhancing anti-leishmania immune response, it is important that a natural product is able to have such an effect when used in vivo. It is noteworthy that $\mathrm{ConBr}$ is a highly abundant lectin in the seeds of a leguminous seed frequently used for human nutrition in Northeastern Brazil. The possibility of enhancing immune response by oral administration of ConBr, as has been shown for other lectin (Luther et al., 1990), deserves further investigation.

\section{Acknowledgments}

We thank Dr. Roberto Diez for assistance in the experiment of kinetics of radiolabelled IFN $-\gamma$. We are indebted to Drs. M. Brandely and Danielle Lando (Institut Roussel Uclaf-France) for her generous gift of rat recombinant IFN- $\gamma$. Mr. Vanilson Souza and Mr. Marcondes Silva provided competent animal care. We thank Mr. Jackson Lemos for secretarial help. R. VonSohsten, and M. Teixeira were recipients of Scientific Initiation Fellowships and M.B-N is a Senior Researcher of the Conselho Nacional de Desenvolvimento Científico e Tecnológico (CNPq). This work was supported by PADCT/CNPq (Brazil).

\section{References}

Andrade, Z.A., Reed, S.G., Roters, S.B., and Sadigursky, M. (1984) Patogenia da leishmaniose cutanea experimental. A importancia da necrose na eliminacao dos parasitas das lesoes. Rev. Soc. Bras. Med. Trop. 17, 187-197.

Badaro, R., Falcoff, E., Badaro, F.S., Carvalho, E.M., Pedral-Sampaio, D., Barral, A., Carvalho, J.S., Barral-Netto, M., Brandely, M., Silva, L., Bina, J.C., Teixeira, R., Falcoff, R., Rocha, H., Ho, J.L., and Johnson, Jr W.D. (1990) Treatment of visceral leishmaniasis with pentavalent antimony and interferon gamma. N. Engl. J. Med. 322, 16-21.

Barral, A., Petersen, E.A., Sacks, D.L., and Neva, F.A. (1983) Late metastatic leishmaniasis in the mouse. A model for mucocutaneous disease. Am. J. Trop. Med. Hyg. 32, 277-285.

Barral, A., Almeida, R., Ribeiro de Jesus A., Neto, E.M., Santos, I.A., and Johnson, W.D. (1987) The relevance of characterizing leishmania from cutaneous lesions. A simple approach for isolation. Mem. Inst. Oswaldo Cruz 82, 579.

Barral, A., Barral-Netto, M., Yong, E.C., Brownell, C.E., Twardzik, D.R., and Reed, S.G. (1993) 
Transforming growth factor-b as a virulence mechanism for Leishmania braziliensis. Proc. Natl. Acad. Sci. USA 90, 3442-3446.

Barral-Netto, M., Freitas, L.A.R., and Andrade, Z.A. (1987a) Histopathological changes induced by vaccination in experimental cutaneous leishmaniasis of BALB/c mice. Am. J. Pathol. 127, 271-278.

Barral-Netto, M., Reed, S.G., Sadigursky, M., and Sonnenfeld, G. (1987b) Specific immunization with solubilized antigen in experimental American cutaneous leishmaniasis. Clin. Exp. Immunol. 67, 11-19.

Barral-Netto, M., Barral, A., Brownell, C.E., Skeiky, Y.A.W., Ellingsworth, L.R., Twardzik, D.R., and Reed, S.G. (1992a) Transforming growth factor-b in leishmanial infection: A parasite escape mechanism. Science 257, 545-548.

Barral-Netto, M., Santos, S.B., Barral, A., Moreira, L.I.M., Santos, C.F., Moreira, R.A., Oliveira, J.T.A., and Cavada, B.S. (1992b) Human lymphocyte stimulation by legume lectins from the Diocleae tribe. Immunol. Invest. 21, 297-303.

Belosevic, M., Finbloom, D.S., Van der Meide, P.H., Sloyter, M.V., and Nacy, C.A. (1989) Administration of monoclonal anti-IFN-gamma antibodies in vivo abrogates natural resistance of $\mathrm{C} 3 \mathrm{H} / \mathrm{HeN}$ mice to infection with Leishmania major. J. Immunol. 143, 266-274.

Black, C.D.V., Kroczek, R.A., Barbet, J., Weinstein, J.N., and Shevach, E.M. (1988) Induction of IL-2 receptor expression in vivo: response to Concanavalin A. Cell. Immunol. 111, 420-432.

Boom, W.H., Liebster, L., Abbas, A.K., and Titus, R.G. (1990) Patterns of cytokine secretion in murine leishmaniasis: Correlation with disease progression or resolution. Infect. Immun. 58, 3863-3870.

Bray, R.S. (1983) Leishmania mexicana mexicana: Attachment and uptake of promastigotes to and by macrophages in vitro. J. Protozool. 30, 314-322.

Dwyer, D.M. (1974) Lectin binding saccharides on a parasitic protozoa. Science 184, 471-473.

Handman, E., and Burgess, A.W. (1979) Stimulation by granulocyte-macrophage colony-stimulating factor of Leishmania tropica-killing by macrophages. J. Immunol. 122, 1134-1137.

Heinzel, F.P., Sadick, M.D., Mutha, S.S., and Locksley, R.M. (1991) Production of interferon gamma, interleukin 2, interleukin 4 , and interleukin 10 by $\mathrm{CD}^{+}$lymphocytes in vivo during healing and progressive murine leishmaniasis. Proc. Natl. Acad. Sci. USA 88, 7011-7015.

Ho, J.L., Reed, S.G., Wick, E.A., and Giordano, M. (1990) Granulocyte-macrophage and macrophage colony-stimulating factors activate intramacrophage killing of Leishmania mexicana amazonensis. J. Infect. Dis. 162, 224-230.

Howard, J.G., Hale, C., and Liew, F.Y. (1981) Immunological regulation of experimental cutaneous leishmaniasis. IV. Prophylactic effect of sub-lethal irradiation as a result of abrogation of suppressor T-cell generation in mice genetically susceptible to Leishmania tropica. J. Exp. Med. 153, 557-568.

Jacobson, R.L., Slutzky, G.M., Greenblatt, C.L., and Schnur, L.F. (1982) Surface reaction of Leishmania I. Lectin-mediated agglutination. Ann. Trop. Med. Parasitol. 76, 45-52.

Kaye, P.M., and Bancroft, G.J. (1992) Leishmania donovani infection in scid mice: Lack of tissue response and in vivo macrophage activation correlates with failure to trigger natural killer cell-derived gamma interferon production in vitro. Infect. Immun. 60, 4335-4342.

Kiderlen, A.F., Kaufman, S.H.E., and Lohmann-Matthes, M.L. (1984) Protection of mice against the intracellular bacterium Listeria monocytogenes by recombinant immune interferon. Eur. J. Immunol. 14, 964-967.

Liew, F.Y., Parkinson, C., Millott, S., Severn, A., and Carrier, M. (1990) Tumor necrosis factor (TNF alpha) in leishmaniasis. I. TNF alpha mediates host protection against cutaneous leishmaniasis. Immunol. 69, 570-573.

Louis, J., Moedder, E., Behin, R., and Engers, H. (1979) Recognition of protozoan parasite antigens by murine $\mathrm{T}$ lymphocytes. I. Induction of specific $\mathrm{T}$ lymphocyte-dependent proliferative responses to Leishmania tropica. Eur. J. Immunol. 9, 841-847.

Luther, P., Reutgen, H., Sehrt, I., Renner, H., Noack, K., Schubert, K-H., and Werchan, D. Orally administered lectin stimulates defence mechanisms in humans, Immunotherapeutic prospects of infectious diseases. Edited by Masihi KN, Lange W. Berlin, Springer-Verlag, 1990, pp 227-231.

Moreira, R.A., and Cavada, B.S. (1984) Lectin from Canavalia brasiliensis (Mart.). Isolation, characterization and behavior during germination. Biologia Plantarum 26, 113-120.

Morris, L., Troutt, A.B., McLeod, K.S., Kelso, A., Handman, E., and Aebischer, T. (1993) Interleukin-4 but not gamma interferon production correlates with the severity of murine cutaneous leishmaniasis. Infect. Immun. 61, 3459-3465.

Muller, I., Garcia-Sanz, J.A., Titus, R., Behin, R., and Louis, J.A. (1989) Analysis of the cellular parameters of the immune responses contributing to resistance and susceptibility of mice to infection with the intracellular parasite, Leishmania major. Immunol. Rev. 112, 95-113. 
Murray, H.W., Masur, H., and Keithly, J.S. (1982) Cell-mediated immune response in experimental visceral leishmaniasis. I. Correlation between resistance to Leishmania donovani and lymphokine generating capacity. J. Immunol. 129, 344-350.

Murray, H.W., Rubin, B.Y., and Rothermel, C.D. (1983) Killing of intracellular Leishmania donovani by lymphokine-stimulated human mononuclear phagocyte. Evidence that interferon $\gamma$ is the activating lymphokine. J. Clin. Invest. 72, 1506-1510.

Murray, H.W., Berman, J.D., and Wright, S.D. (1988) Immunochemotherapy for intracellular Leishmania donovani infection: gamma interferon plus pentavalent antimony. J. Infect. Dis. 157, 973-978.

Murray, H.W. (1990) Effect of continuous administration of interferon- $\gamma$ in experimental visceral leishmaniasis. J. Infect. Dis. 161, 992-994.

Newell, K.A., Ellenhorn, J.D.I., Bruce, D.S., and Bluestone, J.A. (1991) In vivo T-cell activation by staphylococcal enteroxin B prevents outgrowth of a malignant tumor. Proc. Natl. Acad. Sci. USA 88, 1074-1078.

Sadick, M.D., Locksley, R.M., Tubbs, C., and Raff, H.V. (1986) Murine cutaneous leishmaniasis: susceptibility correlates with the capacity to generate interferon-gamma in response to leishmania antigens in vitro. J. Immunol. 136, 655-661.

Sadick, M.D., Heinzel, F.P., Holaday, B.J., Pu, R.T., Dawkins, R.S., and Locksley, R.M. (1990) Cure of murine leishmaniasis with anti-interleukin 4 monoclonal antibody. Evidence for a $T$ cell-dependent, Interferon gamma-independent mechanism. J. Exp. Med. 171, 115-127.

Scott, P., Natovitz, P., Coffman, R.L., Pearce, E., Sher, A. (1988) Immunoregulation of cutaneous leishmaniasis. $T$ cell lines that transfer protective immunity or exacerbation belong to different $T$ helper subsets and respond to distinct parasite antigens. J. Exp. Med. 168, 1675-1684.

Sibley, L.D., and Krahenbuhl, J.L. (1987) Mycobacterium leprae burdened macrophages are refractory to activation by gamma interferon. Infect. Immun. 55, 446-450.

Squires, K.E., Schreiber, R.D., McElrath, M.J., Rubin, B.Y., Anderson, S.L., Murray, H.W. (1989) Experimental visceral leishmaniasis: Role of endogenous IFN-gamma in host defense and tissue granulomatous response. J. Immunol. 143, 4244-4249.

Theodos, C.M., Povinelli, L., Molina, R., Sherry, B., and Titus, R.G. (1991) Role of tumor necrosis factor in macrophage leishmanicidal activity in vitro and resistance to cutaneous leishmaniasis in vivo. Infect. Immun. 59, 2389-2842.

Titus, R.G., Kelso, A., and Louis, J. (1984) Intracellular destruction of Leishmania tropica by macrophages activated with macrophage activating factor/interferon. Clin. Exp. Immunol. 55, 157-165.

Titus, R.G., Ceredig, R., Cerottini, J.C., and Louis, J. (1985) Therapeutic effect of anti-L3T4 monoclonal antibody GK1.5 on cutaneous leishmaniasis in genetically-susceptible BALB/c mice. J. Immunol. 135, 2108-2114.

Titus, R.G., Sherry, B., and Cerami, A. (1989) Tumor necrosis factor plays a protective role in experimental murine cutaneous leishmaniasis. J. Exp. Med. 169, $2097-2104$.

Titus, R.G., Müller, I., Kimsey, P., Cerny, A., Behin, R., Zinkernagel, R.M., and Louis, J.A. (1991) Exacerbation of experimental murine cutaneous leishmaniasis with $\mathrm{CD}^{+}{ }^{+}$Leishmania major-specific $\mathrm{T}$ cell lines or clones which secrete interferon-gamma and mediate parasite-specific delayed-type hypersensitivity. Eur. J. Immunol. 21, 559-567.

Van Dissel, J.T., Stikkelbroeck, J.J.M., Michel, B.C., Van deu Barselarsc, M.T.H., Leijh, P.C.J., and Van Fuhrt, R. (1987) Inability of recombinant interferon $\gamma$ to activate the antibacterial activity of mouse peritoneal macrophages against Listeria monocytogenes and Salmonella typhimurium. J. Immunol. 139, 1673-1678.

Weiser, W.Y., Van Neil, A., Clark, S.C., David, J.R., and Remold, H.G. (1987) Recombinant human granulocyte/macrophage colony-stimulating factor activates intracellular killing of Leishmania donovani by human monocyte-derived macrophages. J. Exp. Med. 166, 1436. 